\title{
The psychology of esports: A systematic literature review
}

\author{
Fanni Bányai ${ }^{1,2}$, Mark D. Griffiths ${ }^{3}$, Orsolya Király ${ }^{1}$, Zsolt Demetrovics $^{1 *}$ \\ ${ }^{1}$ Institute of Psychology, ELTE Eötvös Loránd University, Budapest, Hungary \\ 2 Doctoral School of Psychology, ELTE Eötvös Loránd University, Budapest, Hungary \\ ${ }^{3}$ International Gaming Research Unit, Psychology Department, Nottingham Trent University, \\ Nottingham, UK
}

\section{*Corresponding Author:}

Zsolt Demetrovics

Institute of Psychology, ELTE Eötvös Loránd University

Izabella utca 46., Budapest, 1064, Hungary

Phone: +36 309761097

Fax: +361461 2697

Email address: demetrovics.zsolt@ppk.elte.hu 


\title{
The psychology of esports: A systematic literature review
}

\begin{abstract}
Recently, the skill involved in playing and mastering video games has led to the professionalization of the activity in the form of 'esports' (electronic sports). The aim of the present paper was to review the main topics of psychological interest about esports and then to examine the similarities of esports to professional and problem gambling. As a result of a systematic literature search, eight studies were identified that had investigated three topics: (i) the process of becoming an esport player, (ii) the characteristics of esport players such as mental skills and motivations, and (iii) the motivations of esport spectators. These findings draw attention to the new research field of professional video game playing and provides some preliminary insight into the psychology of esports players. The paper also examines the similarities between esport players and professional gamblers (and more specifically poker players). It is suggested that future research should focus on esport players' psychological vulnerability because some studies have begun to investigate the difference between problematic and professional gambling and this might provide insights into whether the playing of esports could also be potentially problematic for some players.
\end{abstract}

Keywords: Esport; Professional video gaming; Competitive video gaming; Gambling; Poker; Video games; Gaming motivations 


\section{Introduction}

Playing video games has become one of the most popular recreational activities, not just among children and adolescents, but also among adults too (Entertainment Software Association 2017). Video games have changed throughout the past five decades, and have developed from early standalone games such as Space Marines (1962) and Pong (1972) into collaborative and competitive games played via massively multiplayer online environments, where millions of players can play simultaneously against the games' non-player enemies or against other players. More recently, video game playing has become professionalized and for a small minority of players has become a career option in the world of competitive gaming (Faust et al. 2013; Griffiths 2017). This new professional type of video gaming activity has been termed esports (electronic sports). Esport is a new area in the gaming culture, and is starting to become one of the most essential and popular part of video game communities, especially among adolescents and emerging adults.

Competitive video game communities started out in South Korea, and the popularity of FPS (First Person Shooter) games, RTS (Real Time Strategy) games and MMORPGs (Massively Multiplayer Online Role-Playing Games) provided a base for the emerging competitions, not only in Asia, but also in Western countries and regions (Taylor 2012; Wagner 2006). Globally, there are now thousands of video game players who define themselves as professional gamers (i.e., so-called esport players and pro-gamers). Although the FPS and the RTS genres have retained their popularity, the new MOBA (Multiplayer Online Battle Arena) games have become the most popular genre in esports. As a recent global esport market report (Newzoo 2017) noted, the esport economy grew 41.3\% (up to $\$ 696$ million) in 2017 , and esport brand investment is expected to double by 2020 . It is estimated that the global esport audience has reached 385 million, and that $45 \%$ of them play esport games, $23 \%$ view esport streams, and $32 \%$ both play and view esport streams (Newzoo 2017).

There are different definitions of what esports comprise although there are some similar characteristics. Ma and his colleagues (2013) drew attention to the fact that esport players differ from casual gamers. An esports player is a professional gamer who plays for competition, rather than for fun and/or relaxation, and define gaming as their job. Casual gamers play for fun and recreation, and to entertain themselves (Ma et al. 2013). Wagner (2006) provided a detailed definition of esport as "an area of sport activities in which people develop and train mental or physical abilities in the use of information and communication technologies" (Wagner 2006). Hemphill (2005) adds that esports are "alternative sport realities, that is, to electronically extended athletes in digitally represented sporting worlds" (p.199). More pragmatically, esports have been defined as "an umbrella term used to describe organized, sanctioned video game competitions, most often in the context of video game tournaments" (Whalen 2013). In summary, according to these definitions and descriptions, esports are alternate sports, and a special way of using video games and engaging in gameplay (Adamus 2012).

A number of scholars have attempted to theoretically compare esport to other sports confirming the assumption that esport is similar to other sporting activities (Adamus 2012; Taylor 2012; Wagner 2006). According to Guttman's (2004) and Suits' (2007) characteristics that define an activity as sport, esport can be classed as a sport because it includes play (i.e., voluntary, intrinsically motivated activity), the events are organized and governed by rules, 
includes competition with the outcome of a winner and a loser, and comprises skill. Esports also have a large following via online streaming platforms such as Twitch and YouTube. Furthermore, such activities can be played via a Local Area Network (LAN) connection between computer devices, the events are hosted by sponsors, and have esport play-by-play commentaries, jumbotrons (i.e., large televised screens), sizeable live audiences, and large cash prizes for the best gamers (Adamus 2012; Jenny et al. 2016; Jonasson and Thiborg 2010; Lopez-Gonzalez and Griffiths 2016).

Taylor (2012) also highlighted in her work, that the rules of esport tournaments, systems, play, judging, and broadcasting can be similar to traditional sports, and professional gamers can be compared to the requirements and practice of the athletes of professional sports (i.e., training, practice, and physical and mental states of athletes). According to Jenny and his colleagues (2016), two of Guttmann's (2004) criteria need further elaboration before esport being classed as a professional sport. The first criterion concerns physical performance and the extent to which there is a skillful and strategic use of the player's body (because not all of it is used when playing). However, there are many sports in which only specific body parts are used when competing (e.g., darts, snooker, shooting) so this criterion on its own would not rule out esports being classed as a true sport. The second criterion concerns institutional stability, which means esport requires centralized rules for regulation and stabilization to be recognized as a sport, and not just viewed as a juvenile recreation activity (Jenny et al. 2016). The different types of esport games (e.g., first person shooters, MOBA games) with specific rules make it more difficult to achieve institutional stability. However, global esport organizations already exist, like the International e-Sports Federation (IeSF), supporting esport games to be recognized as professional sports, and providing institutional basis for regulation and stabilization (International e-Sports Federation 2017). Nevertheless, it remains a future task to come to a consensus about whether esport is a genuine sport or not.

To understand the background of the new gaming phenomenon of esport, the exploration of the motivational patterns of the video game use is arguably the most important topic. This is particularly relevant because Griffiths (2017) noted that when video gaming becomes an occupation and career where players make a financial living rather than engaging in the activity as a hobby, it potentially changes the motivations of gaming. Many researchers have examined the motivations of gamers, and even if the theoretical basis and the examined video game genres are different, some general and common motivational patterns have been found according to various empirical studies carried out. For instance, Vorderer and his colleagues (Vorderer 2000; Vorderer et al. 2003) found that the most essential elements underlying gaming motivations are interactivity and competition. Interactivity is the opportunity to communicate and cooperate with other gamers in the online environment, and competition is the mechanism by which gamers can compare themselves to each other. Sherry and colleagues (Greenberg et al. 2010; Sherry et al. 2006) outlined similar motivational patterns among grad school and high school students who played video games, including arousal, challenge, competition, distraction, fantasy, and social interactions. According to their findings, motivations were different depending upon the age of the gamer. The most important motivations for younger gamers were competition and challenge (those in the $5^{\text {th }}$ grade), while older gamers were more motivated by challenge, social interactions, arousal and distraction (students in the $8^{\text {th }}$ and $11^{\text {th }}$ grades). 
Yee (2006a, 2006b) explored the motivations of MMORPG players. Among the motivations for playing were achievement motivations (advancement, mechanics, competition), social motivations (socializing, relationship, teamwork), and immersion factors (discovery, role-playing, customization, escapism). The Motivation of Online Games Questionnaire developed by Demetrovics and his colleagues (2011) examined gamer motivations in a more general way. However, their results showed similar motivational patterns among gamers to other empirical studies (i.e., escapism, coping, fantasy, skill development, recreation, competition, and social). One of the common findings of these different studies is that competition is one of the most essential motivations in the playing of video games. Thus, players who identify themselves as a professional esport player should have higher levels of competitive motivation although other playing motivations are also likely to be different from non-professional and casual players. Despite the popularity of esports, few empirical studies appear to have investigated the psychological profile of professional gamers. Furthermore, there are no systematic reviews of the psychological literature to date. Consequently, the present literature review aimed to review recent empirical research that has focused specifically on esport (i.e., professional gaming) from a psychological perspective.

\section{Methods}

The present study aimed to collate and review all the empirical studies concerning esport from a psychological perspective published between 2000 and 2017. Given that competitive gaming only started to occur after videogames could be played online and against other people, the year 2000 was chosen as a start date for the search because the playing of videogames competitively did not exist prior to this date. The data collection included all studies published between January 2000 to July 2017. The literature search comprised the following databases: Google Scholar, Science Direct, PubMed, and Web of Knowledge. The following keywords were used in the respective search engines: 'esport video gam*'; 'professional gam*'; 'pro gam*'; 'competitive video gam*'; 'esport competitive video gam*'; 'sport video gam*' and 'professional video gam*'. Each search was performed not only in titles of the papers, but also in the abstracts (where this option was available) for the following reasons: (i) the title words in the paper can sometimes be limited and may not specifically mention esport; and (ii) the authors could use various synonyms or different terms that equated to the definitions of esport.

A total of 30 papers were found as a result of the systematic search. However, based on the inclusion criteria (i.e., an empirical study containing new primary data and published in a peer reviewed journal in the English language), a total of 22 papers were excluded because they were either non-empirical $(n=11)$, were published in conference proceedings or student theses $(n=8)$, or were not specifically focused on esport $(n=3)$. This left a total of eight empirical studies that met the inclusion requirements (see Table 1). 
Table 1. Summary table of esport focused psychological studies

\begin{tabular}{|c|c|c|c|c|c|c|}
\hline & Study & Country & Sample & $\begin{array}{l}\text { Method and } \\
\text { procedure }\end{array}$ & $\begin{array}{c}\text { Statistical } \\
\text { analysis }\end{array}$ & Main goals of study \\
\hline 1 & $\begin{array}{l}\text { Lee and } \\
\text { Schoenstedt } \\
(2011)\end{array}$ & USA & $\begin{array}{l}515 \text { college } \\
\text { students and } \\
\text { athletic event } \\
\text { attendees }\end{array}$ & $\begin{array}{l}\text { Convenience } \\
\text { sampling method. } \\
\text { Data were } \\
\text { collected in sport } \\
\text { management } \\
\text { related courses, } \\
\text { and at athletic } \\
\text { events on } \\
\text { campuses }\end{array}$ & $\begin{array}{l}\text { Multiple } \\
\text { regression } \\
\text { analysis }\end{array}$ & $\begin{array}{l}\text { To compare esport game } \\
\text { patterns with traditional sport } \\
\text { involvements and to examine } \\
\text { how the related motivations } \\
\text { affect the time spent on } \\
\text { esport gaming. }\end{array}$ \\
\hline 2 & \begin{tabular}{|l} 
Weiss and \\
Schiele (2013)
\end{tabular} & Germany & $\begin{array}{l}360 \text { esport } \\
\text { players }\end{array}$ & $\begin{array}{l}\text { Self-report } \\
\text { questionnaire. } \\
\text { Completed at } \\
\text { World Cyber } \\
\text { Games (WCG) in } \\
\text { Cologne in } \\
\text { November 2008 }\end{array}$ & $\begin{array}{l}\text { Multiple } \\
\text { regression } \\
\text { analysis, } \\
\text { group } \\
\text { comparison } \\
\text { (t- and } \\
\text { F-test), and } \\
\text { Variance } \\
\text { Extracted } \\
\text { (AVE) } \\
\end{array}$ & $\begin{array}{l}\text { To investigate which } \\
\text { competitive and hedonic } \\
\text { needs have influence on } \\
\text { continuous use of esports } \\
\text { according to uses and } \\
\text { gratifications theory. }\end{array}$ \\
\hline 3 & $\begin{array}{l}\text { Lee, An, and } \\
\text { Lee (2014) }\end{array}$ & $\begin{array}{l}\text { South } \\
\text { Korea }\end{array}$ & $\begin{array}{l}103 \text { esport } \\
\text { spectators }\end{array}$ & $\begin{array}{l}\text { Self-report } \\
\text { questionnaire. } \\
\text { Completed at the } \\
2013 \text { League of } \\
\text { Legends World } \\
\text { Championship } \\
\text { Finals at the } \\
\text { Yongsan e-Sports } \\
\text { Stadium on } \\
\text { October 5, 2103. }\end{array}$ & $\begin{array}{l}\text { Bivariate } \\
\text { correlations, } \\
\text { multiple } \\
\text { regression } \\
\text { analysis }\end{array}$ & $\begin{array}{l}\text { To explore the motivational } \\
\text { pattern for watching esport } \\
\text { (more specifically, League of } \\
\text { Legends) broadcasts, and } \\
\text { how these motives effect the } \\
\text { satisfaction of viewers. }\end{array}$ \\
\hline 4 & $\begin{array}{l}\text { Martončik } \\
(2015)\end{array}$ & $\begin{array}{l}\text { Slovakia, } \\
\text { Czech } \\
\text { Republic }\end{array}$ & $\begin{array}{lr}108 \text { esport } \\
\text { players, } 54 \\
\text { casual } \\
\text { players }\end{array}$ & $\begin{array}{l}\text { Self-report } \\
\text { questionnaire. } \\
\text { Sent via e-mail or } \\
\text { directly to in- } \\
\text { game message } \\
\text { systems }\end{array}$ & $\begin{array}{l}\text { Group } \\
\text { comparison } \\
\text { (ANOVA, } \\
\text { independent- } \\
\text { samples t- } \\
\text { test) }\end{array}$ & $\begin{array}{l}\text { To investigate the difference } \\
\text { between esport players (more } \\
\text { specifically, solo vs. team } \\
\text { players, team leaders vs. non- } \\
\text { leaders) and casual players in } \\
\text { gaming motivations, and how } \\
\text { gaming satisfies their life } \\
\text { goals. }\end{array}$ \\
\hline 5 & $\begin{array}{l}\text { Kim and } \\
\text { Thomas } \\
(2015)\end{array}$ & $\begin{array}{l}\text { South } \\
\text { Korea }\end{array}$ & $\begin{array}{l}\text { Nine esport } \\
\text { players, two } \\
\text { team } \\
\text { coaches, two } \\
\text { team } \\
\text { directors and } \\
\text { one } \\
\text { psychological } \\
\text { counselor } \\
\end{array}$ & $\begin{array}{l}\text { Interviews with } \\
\text { the participants } \\
\text { (StarCraft } \\
\text { players, coaches } \\
\text { and psychological } \\
\text { counselor) }\end{array}$ & $\begin{array}{l}\text { Interview } \\
\text { analysis } \\
\text { based on } \\
\text { grounded } \\
\text { theory } \\
\text { methodology } \\
\text { (Glaser and } \\
\text { Strauss } \\
\text { 1967) } \\
\end{array}$ & $\begin{array}{l}\text { To develop the stage theory } \\
\text { model of professional esport } \\
\text { players, where the } \\
\text { motivations (extrinsic and } \\
\text { intrinsic), goals and learning } \\
\text { style change during the } \\
\text { process to become an esport } \\
\text { player. }\end{array}$ \\
\hline
\end{tabular}




\begin{tabular}{|c|c|c|c|c|c|c|}
\hline 6 & Seo (2016) & $\begin{array}{l}\text { South } \\
\text { Korea, } \\
\text { USA, } \\
\text { Australia, } \\
\text { New } \\
\text { Zealand }\end{array}$ & $\begin{array}{l}10 \text { esport } \\
\text { players }\end{array}$ & $\begin{array}{l}\text { (i) Field } \\
\text { observations at } \\
\text { real-world } \\
\text { eSports } \\
\text { tournaments } \\
\text { (South Korea, } \\
\text { USA, Australia, } \\
\text { New Zealand) } \\
\text { (ii) 10 semi- } \\
\text { structured } \\
\text { phenomenological } \\
\text { interviews with } \\
\text { esport players }\end{array}$ & $\begin{array}{l}\text { Subsequent } \\
\text { thematic } \\
\text { analysis } \\
\text { based on a } \\
\text { hermeneutic } \\
\text { interpretive } \\
\text { framework } \\
\text { (Thompson } \\
\text { 1997) }\end{array}$ & $\begin{array}{l}\text { To explore the elements of } \\
\text { esport consumption which } \\
\text { make attractive the } \\
\text { professionalized esport career } \\
\text { for players, to investigate the } \\
\text { reasons why players pursue } \\
\text { this career, and to follow the } \\
\text { players' identity } \\
\text { transformation gamer } \\
\text { professionalized } \\
\text { identity. }\end{array}$ \\
\hline 7 & $\begin{array}{l}\text { Hamari and } \\
\text { Sjöblom } \\
\text { (2017) }\end{array}$ & $\begin{array}{l}\text { Not } \\
\text { specified }\end{array}$ & $\begin{array}{l}888 \text { esport } \\
\text { viewers }\end{array}$ & $\begin{array}{l}\text { Self-reporting } \\
\text { questionnaire, } \\
\text { data was collected } \\
\text { online on eSports } \\
\text { related sub- } \\
\text { Reddits, Twitter, } \\
\text { Facebook, similar } \\
\text { pages }\end{array}$ & $\begin{array}{l}\text { Component- } \\
\text { based PLS- } \\
\text { SEM (Partial } \\
\text { Least } \\
\text { Squares } \\
\text { Structural } \\
\text { Equation } \\
\text { Modeling) } \\
\end{array}$ & $\begin{array}{l}\text { To investigate the } \\
\text { motivational background, } \\
\text { why people watch esport on } \\
\text { the internet. }\end{array}$ \\
\hline 8 & $\begin{array}{l}\text { Himmelstein } \\
\text { et al. (2017) }\end{array}$ & USA & $\begin{array}{l}\text { Five esport } \\
\text { players }\end{array}$ & $\begin{array}{l}\text { Semi-structured } \\
\text { interviews with } \\
\text { competitive } \\
\text { League of Legend } \\
\text { players }\end{array}$ & $\begin{array}{l}\text { Interview } \\
\text { analysis } \\
\text { based on the } \\
\text { inductive } \\
\text { and } \\
\text { deductive } \\
\text { content } \\
\text { analysis (Elo } \\
\text { and Kyngäs } \\
\text { 2008) }\end{array}$ & $\begin{array}{l}\text { To identify the mental skills } \\
\text { and possible obstacles of } \\
\text { esport players to achieve } \\
\text { better performance. }\end{array}$ \\
\hline
\end{tabular}

\section{Results}

The eight studies comprised three main topics: (i) becoming an esport player (i.e., the identity and transformation of esport players), (ii) the characteristics of esport players (mental skills, motivational patterns, etc.), and (iii) the motivations of esport spectators (i.e., why individuals watch esport).

\section{Becoming an esport player}

In a study by Seo (2016), the author focused on different perspectives of esport definition, and examined whether esport was fun or work (or neither) by attending esports tournaments in a number of countries and via in-depth interviews with 10 professional eSports players. Seo's (2016) research goals were threefold, to explore: (i) the elements of esport consumption that make the activity attractive to a career of a professional esport player, (ii) the reasons why esport players want to pursue such a career opportunity, and (iii) how players progress through the identity transformation to aquire a professional gamer identity. Seo (2016) characterized professional esport playing 
as a serious leisure activity, following Stebbins' (1982) definition. Serious leisure can be defined as an intermediate activity between casual leisure and work with beneficial implications, such as gaining self-concept and identity development during the activity (e.g., amateur sport attendance). In Seo's study (2016), professional esport players claimed that the main elements that attracted players to pursue a career in esports were the celebration of the mastery of skills, the pursuit of self-improvement, and the importance of fairness, equity, and mutual respect (i.e., via online/LAN tournaments, formal institutional rules, and the norms and codes of esport government). However, esport players were determined to aquire a professional career, and that the 'journey' gave them opportunity to experience high self-esteem, accomplishment, and social recognition. Even though esport is a serious leisure activity, the professional players still valued the activity as fun and self-motivating. Examining how esport players aquire a professional gamer identity, Seo (2016) identified three stages mapping onto Campbell's (1965) hero's journey monomyth. According to the narratives of esport players, in the first stage ("the call to adventure") players viewed games as casual leisure activity (playing for fun, knowing the mainstream gamer community). However, they started to form initial perceptions and gain interpersonal relationships in the social world of esport. In the second phase ("the road of trials"), they begin the personal transformation to becoming an esport player. For example, they specialize their skills and knowledge about game and mechanics, and their attitudes also change towards gaming and they begin to engage more regularly in esport practices. In the final stage ("the master of two worlds"), professional players aquire a new esport gamer identity. They then find the opportunities to confirm this new identity with other important aspects of their daily lives and their global self-concept of being an esports player.

Similarly to Seo (2016), Kim and Thomas (2015) explored the process how a video game player becomes an esport player utilizing activity theory (Engeström 1993, 1999; Engeström et al. 1999). The authors developed a model explaining the gamers' motivational patterns, changing goals, and learning styles while becoming professional esport players from a more socio-cultural perspective. Kim and Thomas (2015) also highlighted that when trying to define esport, it is important to investigate the complex phenomenon more holistically, including not just the esport players, but also the sponsors, fans, and the whole esport society. From this standpoint, Kim and Thomas (2015) developed their stage theory model of professional video game players by interviewing South Korean professional esport players $(n=9)$, coaches $(n=2)$, team directors $(n=2)$ and a psychological counselor of professional video game play. After all the interviews, five different stages were developed, where the players' performance and motivational patterns can differ. At the beginning, professional gamers are unexperienced and have to solve tasks they have never seen before (enjoying stage). Following this, they improve their skills, lose their intrinsic motivations, and the enjoyment of gaming (struggling stage). When players gain a more developed competency, they experience the enjoyment of the gaming itself again (achieving stage). Unfortunately, most of the players do not maintain the achieving stage, and no longer have the opportunity to play in an official (professional) capacity. They 'lose' the glory and satisfaction they experienced earlier (and enter the slumping stage) before having to recover (recovering stage). The authors drew attention to the motivational patterns that change during the development of an esport player, highlighting the fact that esport players use these particular video games differently from a casual gamer. This means that playing video games in the higher stages of this model are considered as work (extrinsic motivations) rather than leisure (intrinsic motivations). 


\section{The characteristics of esport players}

A recent study by (Himmelstein et al. 2017) interviewing five esport players identified the mental skills and techniques used by esport players in achieving optimal performance in a highly competitive gaming environment. The researchers not only aimed to pinpoint the mental elements of success in esport, but identified the barriers in executing a good performance. For successful performance, emphasized that esport players need to (i) have great knowledge about the video game, (ii) think strategically and make fast and smart decisions, (iii) be motivated to keep moving forward (i.e., not think about the past performances), (iv) be able to separate daily life from performance, (v) avoid being distracted and stay focused, (vi) cope adaptively with the harassment, (vii) maintain a growth mindset (i.e., positive attitude), and (viii) warm up before performance either physically and/or mentally. To achieve optimal performance, it was claimed that players should be able to adapt their opponents, communicate properly with their teammates, and trust their skills. Additionally, they should be capable of developing themselves and their team (i.e., engage in individual skill practice, analyze one's own performance), and set various types of goals (short-term, longterm, process). In addition to the mental elements of performing optimally, the possible barriers of performing were also identified. These barriers related to the elements of optimal performance, such as confidence issues, inadequate coping strategies with anxiety, past achievements and mistakes, harassment, lack of self- and team development (e.g., knowledge about the game, team dynamics, team communication, individual skills), and difficulty in separating life and gaming (Himmelstein et al. 2017).

Three studies focused on exploring the motivations of esport players, examining why such individuals play video games in a competitive way. However, these studies were based on different motivational models. Lee and Schoenstedt (2011) surveyed over 500 college students and athletic event attendees and compared esport to traditional sports by assessing the players' motivations and needs using the theoretical framework of uses and gratifications theory (Katz et al. 1973). Based on previous video game uses and gratifications studies (Kim \& Ross, 2006; Lee, Cheon, Judge, Shin, \& Kim, 2012; Sherry et al. 2006) the authors assessed the following esport related motivations: social interaction, fantasy, identification with sport, diversion, competition, entertainment, sport knowledge application, arousal, design/graphics, passing time, control, skill building, permanence, and peer pressure. The findings demonstrated that personal and social elements of playing video games influenced individuals' interest in esport. The stronger motivations of spending time on esport playing were competition, peer pressure, and skill building for actual playing of sport. Compared to traditional sport behavior involvement, the study explored similarities between esport and traditional sport consumption (i.e., game attendance, game participation, sports viewership, sports readership, sports listenership, online usage specific to sports, and purchase of team merchandise). The televised viewing and online usage showed the greatest involvement in both esport and sport behavior. In addition, the other three sport consumption elements showed similarity among esport and non-esport players. However in-game participation, radio listenership, and team merchandise purchase were less common among esport players than traditional sport players. 
From another theoretical perspective, Weiss and Schiele (2013) surveyed 360 esport players and demonstrated which competitive and hedonic need gratifications drive continuous use of esports according to uses and gratifications theory (Katz et al. 1973). The study found that esports can offer services that fulfill players' needs, confirming previous studies focused on the global gaming motivations of online games and competitive offline games (Mäyrä 2008; Phillips et al. 1995; Sherry et al. 2006; Yee 2006a, 2006b). The competition, challenge, and escapism motivations were identified as the need gratifications obtained through esport. Escapism is a motivation of video game usage in general, and means the player uses a video game to avoid thinking about real-life problems, slipping into the character's role, and becoming a persona that the other players will like. This is one of the most critical motivations in problematic video game play and is one of the factors that predict problematic video game usage (Király et al. 2015; Yee 2006b). From this view, escapism can be considered as a motivation that may jeopardize esport players' video game usage and predict more problematic game-related behavior.

In the third study focused on esport players' motivations, Martončik (2015) investigated different aspects of gaming motivations among esport players $(\mathrm{n}=108)$ and casual gamers $(\mathrm{n}=54)$, and highlighted why professional gamers play video games, and how it satisfied their life goals. Martončik (2015) suggested that the life goals (i.e., intimacy, affiliation, altruism, power, achievement, diversion) of esport or casual players, solo or team players, clan/teamleaders or non-leaders can be different based on the GOALS questionnaire that assessed general long-term life goals (Pöhlmann and Brunstein 1997). Affiliation (i.e., the need to help others, and intense interaction with others) and diversion (i.e., the need for excitement, tension, and new experiences) motivations differentiated the esport players from the casual players, with esport players developing more friendly relationships through membership of a team, and participating in LAN championships. Furthermore, those esport players who were leaders in their teams, also satisfied their need for power by holding a game leader position compared to the non-leader players.

\section{Motivations of esport spectators}

As noted above, esport not only includes players, but also includes organizers and sponsors of esport championships, esports commentators, and the viewing esports audience (Adamus 2012; Jenny et al. 2016; Jonasson and Thiborg 2010). This approach deems it necessary to investigate esport viewers for a more rounded understanding of the phenomenon of professional gaming.

Lee, An, and Lee (2014) examined the characteristics of 103 esport spectators, who attended the 2013 League of Legends World Championship Finals. More specifically, they examined the motives of esport viewing and assessed how these motives affected viewing satisfaction. Findings demonstrated that esport viewers watched professional gaming because they enjoyed the drama that occurred during esport matches, as well as the recreation, game commentary, and skills displayed by the professional gamers. Furthermore, team attachment and game commentary strongly contributed to the satisfaction of esport viewing.

From a different perspective, Hamari and Sjöblom (2017) surveyed 888 esport viewers and investigated esport consumers' motivations, to better understand how and why they used this type of media to satisfy their needs based 
on uses and gratifications theory (Katz et al. 1973). The researchers approached esport as a new sport from the sports consumption and motivation perspective. To understand the game mechanics of any esport game it is indispensable to enjoy esport broadcasting, but the aesthetics motivation (visual elements, attractiveness of the sport/game) did not increase the frequency of esport stream viewing. However, novelty (i.e., enjoyment of seeing new players and teams on the sport scene) had a moderate association with esport consumption, but the enjoyment of aggression (i.e., witnessing aggressive/hostile behavior by the players), escapism (i.e., using media to forget/avoid everyday problems), and acquiring the knowledge (i.e., learning about players and teams, collect information, learn new skills) positively influenced the frequency of esport spectating.

\section{Discussion}

The present review aimed to review all empirical studies examining the psychology of esports, and to draw attention to a new field of video game research. However, as demonstrated via a systematic literature search, few studies exist focusing on the psychological aspects of esports. Findings of the review demonstrated that three main topics have been investigated in the psychological literature: (i) the path of becoming a professional esport player, (ii) characteristics of esport players (i.e., mental skills, motivational patterns), and (iii) the motivational characteristics of watching esport. These studies not only provided data about why professional gamers act in such competitive ways, but also showed that becoming a professional esport player appears to be similar to the process of becoming a professional athlete in any given sport. According to Guttman's (2004) and Suits' (2007) characteristics that define an activity as a sport, many similarities can be found between players who play video games in professional way and players who identify as athletes (e.g., training, practice, skill acquisition, dedication to the 'job', etc.). Taylor (2012) also pointed out in her work that professional gamers and professional athletes of traditional sports can be compared along the same requirements and practices including the fixed rules of tournaments, players' preparation for contests (mentally and physically), broadcasting the events, and judging the events.

However, not all scholars support the concept of considering esport as sport. According to previous game studies, Caillois (2001) argues that competitive gaming in general has a negative impact on people and society when gaming engaged in as a free activity becomes a work activity. Caillois (2001) identified six characteristics of playing (i.e., free, separate, uncertain, unproductive, regulated, and fictive). Considering esport as sport, thus gaming as working activity, these playing characteristics are compromised. The playing activity becomes a part of working life, and can negatively affect the concept of playing as free activity. Building on the work of Caillois (2001), Brock (2017) argued that esport could lead to the pursuit of extrinsic rewards over intrinsic ones by playing video games (Ryan and Deci 2000; Ryan et al. 2006). However, the empirical research cited in the present review demonstrates that esport players can be motivated to become professionals via both extrinsic and intrinsic rewards (Kim \& Thomas, 2015). Moreover, playing video games in a more competitive way does not help define it as a work or leisure activity. It would appear that esport is a serious leisure activity that players enjoy and that some players can develop themselves during the process of becoming professional gamers (Martončik 2015; Seo 2016). Consequently, research is also needed to examine the extent that adolescent gamers are now viewing their playing of videogames as a career 
choice as opposed to a pure leisure activity. Given the increasing appeal of esports, it is likely that increasing numbers of adolescents will see gaming as an activity from which they can make a living.

From a different perspective, Griffiths (2017) raised interesting questions about the role of excessive gaming and potential addictions (Kuss et al. 2016, 2017). In his writings, he theoretically paralleled professional video gaming to professional gamblers (i.e., poker players), focusing on the similarities of the excessive time they can spend on playing which can be either practicing and/or competing. However, the similarities between gambling and playing videogames have been highlighted in papers going back over 25 years. For instance, Griffiths (1991) compared the psychology of playing videogames with the psychology of playing slot machines. He argued that on both a psychological and behavioral level, slot machine gambling and video game playing shared many similarities (e.g., similar demographic differences such as age and gender breakdown, similar reinforcement schedules, similar potential for 'near miss' opportunities, similar structural characteristics involving the use of light and sound effects, similarities in skill perception, and similarities in the effects of excessive play. In fact, Griffiths described gaming as a "non-financial form of gambling" (p.54) and that slot machine gamblers (particularly those with problems) used money as a way of keeping score (in much the same way that gamers do with the points won or lost while playing). Since then, a number of scholars have highlighted the psychological similarities between gambling and video gaming (e.g., Fisher \& Griffiths, 1995; Griffiths, King \& Delfabbro, 2014; Johansson \& Götestam, 2004; Wood, Gupta, Derevensky \& Griffiths, 2004), particularly in the area of structural characteristics and how such features can facilitate repetitive play (e.g., King, Delfabbro \& Griffiths, 2010; Wood, Griffiths, Chappell \& Davies, 2004).

From a problem gambling perspective, future research should focus on esport players' psychological vulnerability, as some studies have begun to investigate the difference between problematic and professional gambling (Hing et al. 2016; Weinstock et al. 2013). According to research focused on the different ways of gambling on the same activity, McCormack and Griffiths (2012) noted, very little empirical research exists investigating professional gamblers who rely upon skill, knowledge, and playing in a more disciplined way than players who only seek entertainment. Further research has observed some identical characteristics which differentiate problematic gamblers and professional gamblers. Weinstock and his colleagues (2013) found both professional and problematic gamblers reported similar frequency and intensity of gambling. However, pathological gamblers showed poor psychosocial functioning, while professionals' rate of psychiatric distress was within a normal range. Further research should be carried out specifically comparing the psychological characteristics of esports players and problem gamers. While the behavior may be identical (i.e., excessive gaming every single day) the motivations are likely to be very different. Hing and her colleagues (2016) differentiated professional, semi-professional, and amateur gamblers from each other, highlighting that problematic use of gambling can appear at every level of this activity. Moreover, those who played at a professional/semiprofessional level, experienced higher psychological distress, and they were more likely report chasing losses and detrimental financial consequences of gambling. Other studies have also reported that professional poker players can suffer from both problematic and addictive play simultaneously (Recher \& Griffiths 2012). Considering that some professional/semi-professional gamblers also appear to display problematic behavior (King et al. 2015) similar research could be carried out on professional esport players. 
Borrowing from the perspective of problematic gambling, further esport research could focus on the fact that professional video game players can also be affected by problematic use due to the level of stress they have to face during practices and competitions. In addition, the lifestyle of esport players can be frenetic, and with the excessive use of games, it can have a negative influence not only on their performance, but on their psychological wellbeing and daily life. In fact, some papers examining excessive professional gaming has questioned whether professional gamers that spend 10 hours or more a day practicing and competing are addicted to gaming or work (Faust et al. 2013; Griffiths 2017).

\section{Conclusion}

The present review systematically collated all the published peer-reviewed empirical studies concerning the psychology of esport players, to draw attention to the topic to academics and researchers in an emerging field of gaming activity, and to encourage future empirical studies in the field of sport psychology. In addition to the increasing popularity and attraction of esport, and the psychology of video gaming more generally, these phenomena are often framed as problematic, because of the lack of physical activity and its sedentary nature (van Hilvoorde 2016; van Hilvoorde and Pot 2016) or the intensive, excessive use (Griffiths 2017). However, there is a paucity of empirical data and further research is needed before any definitive conclusions can be made concerning the psychology of esports. To earn the 'sport-status,' esports need to be accepted as a sport worldwide (van Hilvoorde and Pot 2016; Witkowski 2012, 2009), and is already under consideration in about 40 countries (International eSports Federation 2017).

Regarding future research directions, further comparison and evaluation of sports and esport is needed, developing the similarities and the differences between such activities. Similarly to the previous theoretical studies highlighted (Adamus 2012; Jenny et al. 2016; Jonasson and Thiborg 2010), esport as video gaming consumption is not just a form of leisure activity or work (Ma et al. 2013; Seo 2016; Seo and Jung 2016). Accepting esport as a genuine sport and the emerging popularity of this activity could lead future empirical studies to applying the tools and methodologies of sport psychology in their design. It is also suggested that research carried out into the psychology of professional gambling (e.g., research into activities such as poker) could also provide frameworks and insights applicable to further studying esports. Examining the phenomenon of esport could reduce the stigma that some professional gamers may face (individuals, teams, and staff, including coaches, managers), and also identify and help overcome any potential difficulties (e.g., the process of becoming a professional player, coping with stress during training and/or matches, problematic video game use). 


\section{References}

Adamus, T. (2012). Playing computer games as electronic sport: In search of a theoretical framework for a new research field. In J. Fromme, \& A. Unger (Eds.), Computer games and new media cultures: A handbook of digital games studies (pp. 477-490). Dordrecht: Springer Netherlands.

Brock, T. (2017). Roger Caillois and e-sports: On the problems of treating play as work. Games and Culture, 12(4), 321-339.

Caillois, R. (2001). Man, play and games. Chicago: University of Illinois Press.

Campbell, J. (1965). Hero with 1000 faces. New York: World.

Demetrovics, Z., Urbán, R., Nagygyörgy, K., Farkas, J., Zilahy, D., Mervó, B., ... Harmath, E. (2011). Why do you play? The development of the motives for online gaming questionnaire (MOGQ). Behavior Research Methods, 43(3), 814-825.

Elo, S., \& Kyngäs, H. (2008). The qualitative content analysis process. Journal of Advanced Nuring, 62(1), $107-115$.

Engeström, Y. (1993). Developmental studies of work as a testbench of activity theory: The case of primary care medical practice. In S. Chaiklin, \& J. Lave (Eds.), Understanding practice: Perspectives on activity and context (pp. 64-103). Cambridge: Cambridge University Press.

Engeström, Y. (1999). Activity theory and individual and social transformation. In Y. Engeström, R. Miettinen, \& R.-L. Punamäki (Eds.), Perspectives on activity theory (pp. 19-38). Cambridge: University Press.

Engeström, Y., Miettinen, R., \& Punamäki, R.-L. (1999). Perspectives on activity theory. Cambridge: Cambridge University Press.

Entertainment Software Association (2017). Essential facts about the computer and video game industry. Retrieved February 8, 2017, from: http:/www.theesa.com/wp-content/uploads/2017/04/EF2017 FinalDigital.pdf.

Faust, K., Meyer, J., \& Griffiths, M. D. (2013). Competitive and professional gaming: Discussing potential benefits of scientific study. International Journal of Cyber Behavior, Psychology and Learning, 3(1), 67-77.

Glaser, B., \& Strauss, A. (1967). Grounded theory: The discovery of grounded theory. Sociology, 12, 27-49.

Fisher, S. E., \& Griffiths, M. D. (1995). Current trends in slot machine gambling: Research and policy issues. Journal of Gambling Studies, 11, 239-247.

Greenberg, B. S., Sherry, J., Lachlan, K., Lucas, K., \& Holmstrom, A. (2010). Orientations to video games among gender and age groups. Simulation \& Gaming, 41(2), 238-259.

Griffiths, M. D. (1991). Amusement machine playing in childhood and adolescence: A comparative analysis of video games and fruit machines. Journal of Adolescence, 14, 53-73.

Griffiths, M. (2017). The psychosocial impact of professional gambling, professional video gaming \& eSports. Casino \& Gaming International, 28, 59-63.

Griffiths, M. D., King, D. L. \& Delfabbro, P. H. (2014). The technological convergence of gambling and gaming practices. In Richard, D.C.S., Blaszczynski, A. \& Nower, L. (Eds.). The Wiley-Blackwell handbook of disordered gambling (pp. 327-346). Chichester: Wiley.

Guttmann, A. (2004). From ritual to record: The nature of modern sports. New York: Columbia University Press.

Hamari, J., \& Sjöblom, M. (2017). What is eSports and why do people watch it? Internet Research, 27(2), 211-232.

Hemphill, D. (2005). Cybersport. Journal of the Philosophy of Sport, 32(2), 195-207.

Himmelstein, D., Liu, Y., \& Shapiro, J. L. (2017). An exploration of mental skills among competitive League of Legend players. International Journal of Gaming and Computer-Mediated Simulations, 9(2), 1-21.

Hing, N., Russell, A. M., Gainsbury, S. M., \& Blaszczynski, A. (2016). A case of mistaken identity? A comparison of professional and amateur problem gamblers. Journal of Gambling Studies, 32(1), 277-289.

International e-Sports Federation (2017). Member Nations. Retrieved February 8, 2018, from: http://www.iesf.org/about/\#member-nations.

Jenny, S. E., Manning, R. D., Keiper, M. C., \& Olrich, T. W. (2016). Virtual(ly) athletes: Where esports fit within the definition of "sport". Quest. Epub ahead of print. doi:10.1080/00336297.2016.1144517.

Johansson, A., \& Götestam, K. G. (2004). Problems with computer games without monetary reward: Similarity to pathological gambling. Psychological Reports, 95(2), 641-650.

Jonasson, K., \& Thiborg, J. (2010). Electronic sport and its impact on future sport. Sport in Society, 13(2), $287-299$.

Katz, E., Blumler, J. G., \& Gurevitch, M. (1973). Uses and gratifications research. The Public Opinion Quarterly, 37(4), 509-523.

Kim, S. H., \& Thomas, M. K. (2015). A stage theory model of professional video game players in South Korea: The socio-cultural dimensions of the development of expertise. Asian Journal of Information Technology, 14(5), 176-186. 
Kim, Y., \& Ross, S. D. (2006). An exploration of motives in sport video gaming. International Journal of Sports Marketing and Sponsorship, 8(1), 28-40.

King, D. L., Delfabbro, P. H. \& Griffiths, M. D. (2010). Video game structural characteristics: A new psychological taxonomy. International Journal of Mental Health and Addiction, 8, 90-106.

King, D. L., Gainsbury, S. M., Delfabbro, P. H., Hing, N., \& Abarbanel, B. (2015). Distinguishing between gaming and gambling activities in addiction research. Journal of Behavioral Addictions, 4(4), 215-220.

Király, O., Nagygyörgy, K., Koronczai, B., Griffiths, M. D., \& Demetrovics, Z. (2015). Assessment of problematic internet use and online video gaming. In E. Aboujaoude, \& V. Starcevic (Eds.), Mental health in the digital age: Grave dangers, great promise (pp. 46-68). New York: Oxford University Press.

Kuss, D. J., Griffiths, M. D., \& Pontes, H. M. (2016). Chaos and confusion in DSM-5 diagnosis of Internet Gaming Disorder: Issues, concerns, and recommendations for clarity in the field. Journal of Behavioral Addictions, 6(2), 103-109.

Kuss, D. J., Griffiths, M. D., \& Pontes, H. M. (2017). DSM-5 diagnosis of Internet Gaming Disorder: Some ways forward in overcoming issues and concerns in the gaming studies field: Response to the commentaries. Journal of Behavioral Addictions, 6(2), 133-141.

Lee, D., Cheon, W., Judge, L., Shin, H., \& Kim, K. (2012). Motives and marketing stimuli affecting esports consumption: Cross-cultural perspectives. International Journal of Sport Management, 13(2), 203-223.

Lee, D., \& Schoenstedt, L. J. (2011). Comparison of eSports and traditional sports consumption motives. The ICHPER-SD Journal of Research in Health, Physical Education, Recreation, Sport \& Dance, 6(2), 39-44.

Lee, J.-Y., An, J.-W., \& Lee, S.-W. (2014). Factors affecting eSports audience satisfaction-The case of League of Legends. Journal of Korea Game Society, 14(3), 35-46.

Lopez-Gonzalez, H., \& Griffiths, M. D. (2016). Understanding the convergence of markets in online sports betting. International Review for the Sociology of Sport. Epub ahead of print. doi: 10.1177/1012690216680602

Ma, H., Wu, Y., \& Wu, X. (2013). Research on essential difference of e-sport and online game. In W. Du (Ed.), Informatics and management science V (pp. 615-621). London: Springer.

Martončik, M. (2015). e-Sports: Playing just for fun or playing to satisfy life goals? Computers in Human Behavior, $48,208-211$.

Mäyrä, F. (2008). An introduction to game studies. London: Sage Publications Ltd.

McCormack, A., \& Griffiths, M. D. (2012). What differentiates professional poker players from recreational poker players? A qualitative interview study. International Journal of Mental Health and Addiction, 10(2), 243257.

Newzoo (2017). Global Esports Market Report 2017. Retrieved February 8, 2018, from: https://newzoo.com/insights/trend-reports/global-esports-market-report-2017-light/

Phillips, C. A., Rolls, S., Rouse, A., \& Griffiths, M. D. (1995). Home video game playing in schoolchildren: A study of incidence and patterns of play. Journal of Adolescence, 18(6), 687-691.

Pöhlmann, K., \& Brunstein, J. C. (1997). GOALS: Ein fragebogen zur messung von lebenszielen. Diagnostica, $43(1), 103-119$

Recher, J., \& Griffiths, M. D. (2012). An exploratory qualitative study of online poker professional players. Social Psychological Review, 14(2), 13-25.

Ryan, R. M., \& Deci, E. L. (2000). Intrinsic and extrinsic motivations: Classic definitions and new directions. Contemporary Educational Psychology, 25(1), 54-67.

Ryan, R. M., Rigby, C. S., \& Przybylski, A. (2006). The motivational pull of video games: A self-determination theory approach. Motivation and Emotion, 30(4), 344-360.

Seo, Y. (2016). Professionalized consumption and identity transformations in the field of eSports. Journal of Business Research, 69(1), 264-272, doi:http://dx.doi.org/10.1016/j.jbusres.2015.07.039.

Seo, Y., \& Jung, S.-U. (2016). Beyond solitary play in computer games: The social practices of eSports. Journal of Consumer Culture, 16(3), 635-655.

Sherry, J. L., Lucas, K., Greenberg, B. S., \& Lachlan, K. (2006). Video game uses and gratifications as predictors of use and game preference. In P. Vorderer, \& J. Bryant (Eds.), Playing video games: Motives, responses, and consequences (pp. 213-224). Mahwah, NJ: Lawrence Erlbaum Associates.

Stebbins, R. A. (1982). Serious leisure: A conceptual statement. Pacific Sociological Review, 25(2), 251-272.

Suits, B. (2007). The elements of sport. Ethics in Sport, 2, 9-19.

Taylor, T. (2012). Raising the stakes: E-sports and the professionalization of computer gaming. Cambridge: The MIT Press.

Thompson, C. J. (1997). Interpreting consumers: a hermeneutical framework for deriving marketing insights from the texts of consumers' consumption stories. Journal of Marketing Research, 34, 438-455. 
van Hilvoorde, I. (2016). Sport and play in a digital world. Sport, Ethics and Philosophy, 10(1), 1-4, doi:10.1080/17511321.2016.1171252.

van Hilvoorde, I., \& Pot, N. (2016). Embodiment and fundamental motor skills in eSports. Sport, Ethics and Philosophy, 10(1), 14-27, doi:10.1080/17511321.2016.1159246.

Vorderer, P. (2000). Interactive entertainment and beyond. In D. Zillman, \& P. Vorderer (Eds.), Media entertainment: The psychology of its appeal (pp. 21-36). Mahwah, NJ: Lawrence Erlbaum Associates.

Vorderer, P., Hartmann, T., \& Klimmt, C. (2003, May). Explaining the enjoyment of playing video games: the role of competition. Paper presented at the Proceedings of the Second International Conference on Entertainment Computing, Pittsburgh, Pennsylvania, USA

Wagner, M. G. (2006). On the scientific relevance of eSports. In: International Conference on Internet Computing \& Conference on Computer Games Development. LasVegas, NV: ICOMP.

Weinstock, J., Massura, C. E., \& Petry, N. M. (2013). Professional and pathological gamblers: Similarities and differences. Journal of Gambling Studies, 29(2), 205-216.

Weiss, T., \& Schiele, S. (2013). Virtual worlds in competitive contexts: Analyzing eSports consumer needs. Electronic Markets, 23(4), 307-316.

Whalen, S. J. (2013). Cyberathletes' lived experience of video game tournaments. Doctoral dissertation, University of Tennessee,

Witkowski, E. (2009). Probing the sportiness of eSports. In J. Christophers, \& T. Scholz (Eds.), eSports yearbook (pp. 53-56). Norderstedt, Germany: Books on Demand GmbH.

Witkowski, E. (2012). On the digital playing field: How we "do sport" with networked computer games. Games and Culture, 7(5), 349-374.

Wood, R. T. A., Griffiths, M. D., Chappell, D. \& Davies, M. N. O. (2004). The structural characteristics of video games: A psycho-structural analysis. CyberPsychology and Behavior, 7, 1-10.

Wood, R. T. A., Gupta, R., Derevensky, J. \& Griffiths, M. D. (2004). Video game playing and gambling in adolescents: Common risk factors. Journal of Child and Adolescent Substance Abuse 14, 77-100.

Yee, N. (2006a). The demographics, motivations, and derived experiences of users of massively multi-user online graphical environments. Presence: Teleoperators and Virtual Environments, 15(3), 309-329.

Yee, N. (2006b). Motivations for play in online games. CyberPsychology \& Behavior, 9(6), 772-775. 